\title{
REVIEW
}

\section{Bench-to-bedside review: The role of C1-esterase inhibitor in sepsis and other critical illnesses}

\author{
Mervyn Singer ${ }^{* 1}$ and Annie M Jones²
}

\begin{abstract}
The purpose of this bench-to-bedside review is to summarize the literature relating to complement activation in sepsis and other critical illnesses and the role of $\mathrm{C} 1$-esterase inhibitor $(\mathrm{C} 1 \mathrm{INH})$ as a potential therapy.
\end{abstract}

\section{Sepsis and complement}

The complement system is a crucial part of the body's defense mechanism against bacterial infection and is vital for protecting individuals against any disturbance of homeostasis associated with the appearance of foreign antigens [1]. Activation of the complement system can be initiated through the classic pathway antigen-antibody complexes or through the alternative and lectin pathways by non-immunologic molecules such as endotoxin (Figure 1). The complement system orchestrates the immunologic network and links to elements of both innate and adaptive immunity and is an important inducer of an excessive inflammatory host response and contributes to the clinical course, prognosis, and complications of sepsis $[2,3]$. Complement is activated early in sepsis (especially clinical sepsis) $[4,5]$ and other conditions involving inflammation or immunologic alterations [6-8]. Bradykinin, complement factors, contact system components, estrogen, protease deficiencies, and genetic polymorphisms are also implicated in certain types of non-allergic angioedema, including hereditary and druginduced [9].

C1-esterase inhibitor (C1 INH) is an alpha-globulin controlling the first part of the classic complement pathway and is a natural inhibitor of complement and contact system proteases [10] and a major downregulator of inflammatory processes in blood [11] (Table 1). C1 is

\footnotetext{
*Correspondence: m.singer@ucl.ac.uk

'Bloomsbury Institute of Intensive Care Medicine, University College London,

Cruciform Buildng, Gower Street, London, WC1E 6BT, UK

Full list of author information is available at the end of the article
}

the primary regulator of the plasma kallikrein-kinin system as evidenced by a lack of kallikrein inhibitory capability in plasma taken from patients with hereditary angioedema [12] and can also inactivate other proteases, including plasmin and tissue plasminogen activator, although the in vivo significance remains unclear [8]. During sepsis, an overactive complement system may compromise the effectiveness of innate immunity $[5,13]$.

Other activities of $\mathrm{C} 1$ include interactions with endogenous proteins, with cells, and with infectious agents [8]. In addition to binding to endotoxin from Gramnegative bacteria, C1 may bind to streptococcal lipoteichoic acid [14]. These may have potentially important functional consequences that are not dependent on protease inhibition.

Activation of the complement cascade can be triggered via the alternative complement pathway and the mannosebinding lectin pathway. When these converge with the classic complement pathway (Figure 1), the C3-convertase is formed. This cleaves C3 into C3a and the opsonizing $\mathrm{C} 3 \mathrm{~b}$, which contributes to the formation of C5-convertase [15]. C5-convertase subsequently cleaves $\mathrm{C} 5$ into the anaphylatoxin $\mathrm{C} 5 \mathrm{a}$ and $\mathrm{C} 5 \mathrm{~b}$, thereby initiating formation of the terminal membrane attack complex, consisting of C5b and C6-9 [15]. In sepsis, complement system activation is evidenced by the presence of the complement activation products $\mathrm{C} 3 \mathrm{a}, \mathrm{C} 5 \mathrm{a}$, and $\mathrm{C} 5 \mathrm{~b}-9$ in plasma [6]. These anaphylatoxins have a spectrum of proinflammatory activities [6]. In addition, there is a loss of C5a receptors (C5aRs) on blood polymorphonuclear neutrophils (PMNs) in patients with septic shock [6]. When C5a interacts with blood PMNs, signalling pathways are paralyzed. This paralysis results in the loss of their innate immune function and likely contributes to the harmful consequences of sepsis [16]. Complement C5a has also been implicated in the pathogenesis of septic cardiac dysfunction [17].

Complement may interact with other systems in sepsis. This has been comprehensively reviewed by Rittirsch and colleagues [7]. For example, it has been linked to the coagulation pathway which, when activated during sepsis, may predispose to thrombosis and disseminated intravascular coagulation [7]. The resulting generation of 


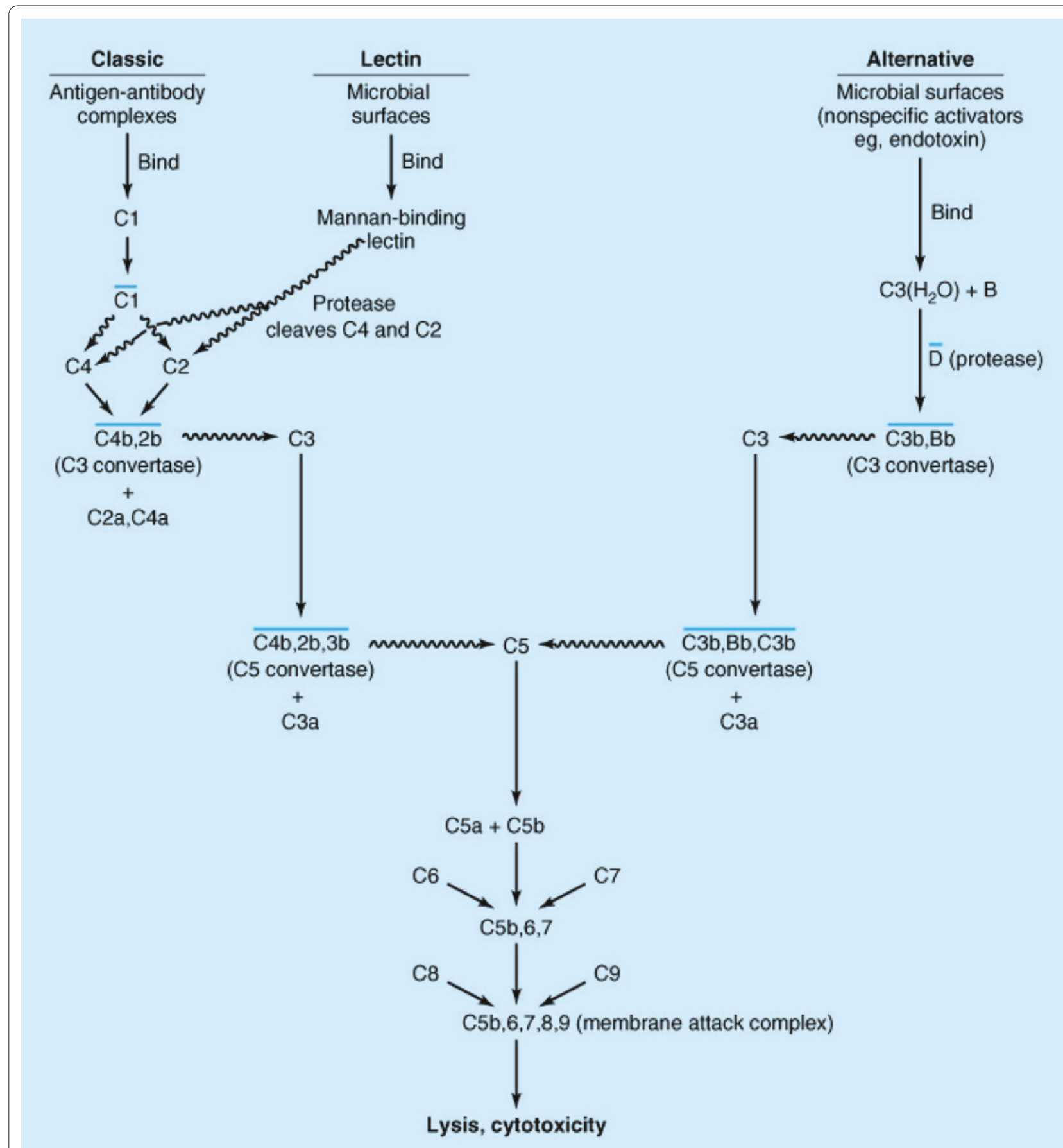

Figure 1. The classic and alternative pathways of the complement system. The squiggly line arrows indicate that proteolytic cleavage of the molecule at the tip of the arrow has occurred; a line over a complex indicates that it is enzymatically active. Note that the nomenclature of the cleavage products of C2 is undecided. Some call the large fragment C2a and others call it C2b. Here, all small fragments are labeled 'a' and all large fragments are labeled ' $b$ '. Hence, the $C 3$ convertase is depicted as $C 4 b, 2 b$. Note that proteases associated with the mannose-binding lectin cleave C4 as well as C2. Reprinted with permission from McGraw-Hill Medical [67].

thrombin will aggravate the excessive inflammatory response and further complement system activation and may be involved in the increased rate of apoptosis of lymphocytes and splenocytes, causing a marked decrease in cell numbers and resulting immunoparesis. Paradoxically, the apoptosis of macrophages and neutrophils seems to be unaffected or even delayed. Complement may also interact with the autonomic nervous system, 
Table 1. Activities of C1 inhibitor

\begin{tabular}{ll}
\hline Protease inhibition & \\
$\begin{array}{l}\text { Complement system } \\
\text { Plasma kallikrein-kinin system } \\
\text { Fibrinolytic system }\end{array}$ & Plasma kallikrein, factor XII \\
Coagulation system & Plasmin, tissue plasminogen activator \\
Interactions with endogenous proteins & Factor XI, thrombin \\
Complement system & C3b \\
Extracellular matrix & Type IV collagen, laminin, entactin, fibrin \\
Interactions with cells & \\
Circulating cells & Neutrophils, macrophages \\
Vascular cells & Endothelial cells (E and P selectins) \\
Interactions with infectious agents & \\
Endotoxin & Escherichia coli 011:B4, E. Coli 0127:B5, E. Coli 055:B5, E. Coli K-235, Salmonella typhimurium, Salmonella \\
Bacteria & minnesota, Salmonella typhosa \\
Parasites & Bordetella pertussis, E. coli, Serratia marcescens \\
\hline
\end{tabular}

Reprinted with permission from Elsevier [8].

which is also dysregulated in sepsis. Further investigations are needed to establish the significance of these various interactions and the identification of new therapeutic targets.

\section{C1 inhibitor}

As stated above, the biological activities of $\mathrm{C} 1 \mathrm{INH}$ include the inactivation of a variety of proteases, including complement system proteases ( $\mathrm{C} 1 \mathrm{r}, \mathrm{C} 1 \mathrm{~s}$, and MASP2), contact system proteases (factor XII, plasma, and kallikrein), intrinsic coagulation proteases (factor XI), and fibrinolytic proteases (plasmin and tissue plasminogen activator) (Table 1) [8]. In addition to inhibiting proteases, $\mathrm{C} 1 \mathrm{INH}$ interacts with extracellular matrix components, the complement component C3, endothelial cells and leukocytes, and endotoxin.

C1 INH is licensed in Europe and the US for the management of hereditary angioedema (including acute attacks and routine prophylaxis). In addition, over the past 20 years, administration of $\mathrm{C} 1 \mathrm{INH}$ has been associated with improved survival or correction (or both) of biochemical parameters in a variety of clinical scenarios. However, these have been predominantly lab-based studies; human investigations have been mainly at the level of individual anecdote, small case series, or small randomized controlled trials. Table 2 summarizes the research and clinical studies included in the present review.

\section{Animal models}

\section{Sepsis and endotoxic shock}

C1 INH improves outcomes in animal models of sepsis. Croner and colleagues [18] reported a reduction in hepatic leukocyte-endothelial interactions in post-sinusoidal venules and an improved hepatic perfusion in lipopolysaccharide-induced sepsis in rats. Decreased leukocyte adherence and suppression of the increase in vascular permeability were also demonstrated in both rats and mice treated with $\mathrm{C} 1 \mathrm{INH}[19,20]$. Fischer and colleagues [21] reported improved survival in C3-deficient mice challenged with endotoxin and also demonstrated the role of complement in endotoxin clearance. In a rabbit model, combined anti-thrombin and $\mathrm{C} 1 \mathrm{INH}$ treatment during early endotoxic shock decreased organ fibrin deposition and improved cardiovascular stability [22]. Treatment with $\mathrm{C} 1 \mathrm{INH}$ also prevented the hypoxemia induced by endotoxic shock in dogs [23] and decreased cytokine production in both primates [24] and mice [25].

In a cecal ligation and puncture (CLP) models of sepsis, treatment with a single dose of $\mathrm{C} 1 \mathrm{INH}$ improved survival [26]. This improvement was enhanced by the administration of multiple doses. However, survival was not improved with a single dose at 6 hours rather than immediately after puncture but was improved when two doses were given at 3 and 9 hours after CLP. This finding led to the suggestion that the effectiveness of $\mathrm{C} 1 \mathrm{INH}$ treatment in sepsis may relate, at least in part, to its ability to enhance phagocytosis rather than inhibit the complement and contact systems.

\section{Ischemia-reperfusion injury and acute pancreatitis}

Animal studies have shown that administration of $\mathrm{C} 1$ $\mathrm{INH}$ at or just prior to reperfusion results in a reduction in myocardial injury; reduced plasma levels of creatine 
Table 2. Laboratory and clinical studies of C1-esterase inhibitor

\begin{tabular}{|c|c|c|c|c|c|}
\hline $\begin{array}{l}\text { Type of } \\
\text { study }\end{array}$ & Indication & $\begin{array}{l}\text { Model/Study } \\
\text { type }\end{array}$ & Objective & Findings & Reference \\
\hline \multirow[t]{17}{*}{ Laboratory } & Sepsis & Rat & $\begin{array}{l}\text { Influence of } \mathrm{C} 1 \mathrm{INH} \text { on microcirculation } \\
\text { and leukocyte-endothelial interaction } \\
\text { in the liver }\end{array}$ & $\begin{array}{l}\text { Leukocyte sticking to the endothelial wall in } \\
\text { post-sinusoidal venules was reduced in } \mathrm{C} 1 \mathrm{INH} \text { rats. } \\
\text { Hepatic microcirculatory disturbances may be } \\
\text { reduced by } \mathrm{C} 1 \mathrm{INH} \text {. }\end{array}$ & [18] \\
\hline & & Baboon & $\begin{array}{l}\text { Effect of } \mathrm{C} 1 \mathrm{INH} \text { on physiologic and } \\
\text { inflammatory response }\end{array}$ & $\begin{array}{l}\text { C1 INH did not prevent the hemodynamic/ } \\
\text { hematologic changes. Activation of fibrinolysis and } \\
\text { development of intravascular coagulation were } \\
\text { unaffected. C1 INH reduced decreases in plasma levels } \\
\text { of factor XII and prekallikrein and abrogated the systemic } \\
\text { appearance of C } 4 \mathrm{~b} / \mathrm{c} \text { and reduced elaboration of } \\
\text { various cytokines. }\end{array}$ & ic \\
\hline & & Mouse & Effect on survival & $\begin{array}{l}\text { C1 INH blocked LPS-binding protein-dependent } \\
\text { binding and suppressed LPS-induced TNF-a mRNA } \\
\text { expression. }\end{array}$ & {$[25]$} \\
\hline & & Mouse & Effect on survival & $\begin{array}{l}\text { C1 INH enhanced the bactericidal activity of blood } \\
\text { neutrophils and peritoneal exudate leukocytes. } \\
\text { Survival increased with } \mathrm{C} 1 \mathrm{INH} \text {. }\end{array}$ & {$[26]$} \\
\hline & $\begin{array}{l}\text { Experimental } \\
\text { endotoxemia }\end{array}$ & Rat & $\begin{array}{l}\text { Effects of } \mathrm{C} 1 \mathrm{INH} \text { on arterial } \\
\text { oxygenation and tissue oxygenation } \\
\text { of jejunal mucosa during endotoxemia }\end{array}$ & $\begin{array}{l}\text { Decrease in arterial oxygenation was attenuated by } \\
\text { pre-treatment with C1 INH. Tissue oxygenation } \\
\text { decreased in LPS and C1 INH groups without } \\
\text { significant difference after } 120 \text { minutes of endotoxemia. } \\
\text { Endotoxin-induced tissue hypoxia of the intestinal } \\
\text { mucosa was not prevented by } \mathrm{C} 1 \mathrm{INH} \text {. }\end{array}$ & [19] \\
\hline & & Rat & $\begin{array}{l}\text { Effects of } \mathrm{C} 1 \mathrm{INH} \text { on intestinal } \\
\text { functional capillary density, leukocyte } \\
\text { adherence, and mesenteric plasma } \\
\text { extravasation }\end{array}$ & $\begin{array}{l}\text { C1 INH reduced endotoxemia ( } 9.5 \%) \text { and attenuated } \\
\text { intestinal leukocyte adherence in submucosal } \\
\text { venules ( } 35 \%) \text { and mesenteric plasma extravasation } \\
(44 \%) \text {. C1 INH diminished changes in the intestinal } \\
\text { microcirculation. }\end{array}$ & {$[20]$} \\
\hline & & Mouse & $\begin{array}{l}\text { Investigate the role of complement in } \\
\text { endotoxic shock }\end{array}$ & $\begin{array}{l}\text { C3- and C4-deficient mice were significantly more } \\
\text { sensitive to endotoxin. C1 INH had a protective } \\
\text { effect against endotoxin. }\end{array}$ & [21] \\
\hline & & Rabbit & $\begin{array}{l}\text { Effect of antithrombin III }+\mathrm{C} 1 \mathrm{INH} \text { on } \\
\text { intravascular organ fibrin deposition } \\
\text { and cardiorespiratory changes }\end{array}$ & $\begin{array}{l}\text { Combined treatment was associated with decreased } \\
\text { clot formation in lungs and livers. There was no clear } \\
\text { dose-dependent effect. }\end{array}$ & [22] \\
\hline & & Dog & $\begin{array}{l}\text { Effect on cardiovascular and } \\
\text { respiratory dysfunction }\end{array}$ & C1 INH prevented hypoxemia. & {$[23]$} \\
\hline & $\begin{array}{l}\text { Ischemia- } \\
\text { reperfusion } \\
\text { injury }\end{array}$ & Cat & Cardioprotective effect & $\begin{array}{l}\mathrm{C} 1 \mathrm{INH} \text { improved recovery of cardiac contractility } \\
\text { and preservation of coronary vascular endothelial } \\
\text { function. }\end{array}$ & {$[27]$} \\
\hline & & Rat & Cardioprotective effect & $\begin{array}{l}\text { C1 INH attenuated myocardial injury and neutrophil } \\
\text { infiltration even after } 48 \text { hours of reperfusion. }\end{array}$ & {$[28]$} \\
\hline & & Rat & $\begin{array}{l}\text { Effect on C3 activity in ischemic } \\
\text { myocardial tissue }\end{array}$ & $\begin{array}{l}\text { C1 INH suppressed C3 mRNA expression and protein } \\
\text { synthesis and prevented myocardial cell injury. }\end{array}$ & [32] \\
\hline & & Rat & $\begin{array}{l}\text { Protection against myocardial } \\
\text { cell injury }\end{array}$ & $\begin{array}{l}\text { C1 INH improved cardiac function and hemodynamics } \\
\text { and reduced myocardial infarct size. }\end{array}$ & {$[31]$} \\
\hline & & Mouse & $\begin{array}{l}\text { Role and mechanism of } \mathrm{C} 1 \mathrm{INH} \text { in } \\
\text { alleviating intestinal injury }\end{array}$ & $\begin{array}{l}\mathrm{C} 1 \mathrm{INH} \text { reduced intestinal tissue injury and attenuated } \\
\text { leukocyte infiltration and improved survival. }\end{array}$ & [33] \\
\hline & $\begin{array}{l}\text { Acute } \\
\text { pancreatitis }\end{array}$ & Mouse/Rat & Evaluate the effect of $\mathrm{C} 1 \mathrm{INH}$ & $\begin{array}{l}\text { C1 INH slightly ameliorated the degree of histological } \\
\text { alterations, but increase in serum amylase was reduced } \\
\text { in diet-induced pancreatitis only. C1 INH did not improve } \\
\text { survival in taurocholate- and diet-induced pancreatitis. }\end{array}$ & [35] \\
\hline & $\begin{array}{l}\text { Xenotrans- } \\
\text { plantation }\end{array}$ & Pig & $\begin{array}{l}\text { Inhibition of complement-mediated } \\
\text { cytotoxicity and activation of } \\
\text { endothelial cells }\end{array}$ & $\mathrm{C} 1 \mathrm{INH}$ inhibited $\mathrm{C} 1$ activation. & [38] \\
\hline & & Pig & Effect on hyperacute rejection & $\begin{array}{l}\text { Survival improved. C1 INH inhibited complement } \\
\text { activation, and no contact activation was found. } \\
\text { Leukocytes and platelet activation were reduced } \\
\text { by C1 INH. }\end{array}$ & [39] \\
\hline
\end{tabular}


Table 2. Continued

\begin{tabular}{|c|c|c|c|c|c|}
\hline $\begin{array}{l}\text { Type of } \\
\text { study }\end{array}$ & Indication & $\begin{array}{l}\text { Model/Study } \\
\text { type }\end{array}$ & Objective & Findings & Reference \\
\hline \multirow[t]{6}{*}{ Laboratory } & $\begin{array}{l}\text { Xenotrans- } \\
\text { plantation }\end{array}$ & Pig & Effect on hyperacute rejection & $\begin{array}{l}\mathrm{C} 1 \mathrm{INH} \text { attenuated hyperacute rejection by } \\
\text { decreasing the activation of adhesion molecules. }\end{array}$ & [41] \\
\hline & & Pig & Effect on hyperacute rejection & $\begin{array}{l}\mathrm{C} 1 \mathrm{INH} \text { at } 10 \mathrm{U} / \mathrm{mL} \text { prolonged survival time and } \\
\text { diminished complement activation but did not } \\
\text { prevent rapid lung injury. }\end{array}$ & [42] \\
\hline & & Pig & Effect on hyperacute rejection & C1 INH improved pulmonary function but not survival. & [40] \\
\hline & & Pig/Monkey & Effect on hyperacute rejection & $\begin{array}{l}\mathrm{C} 1 \mathrm{INH} \text { therapy with standard immunosuppressive } \\
\text { regimen prevented rejection but did not improve } \\
\text { survival. }\end{array}$ & {$[43,44]$} \\
\hline & Thermal injury & Pig & $\begin{array}{l}\text { Effect on capillary leak syndrome and } \\
\text { inflammatory tissue destruction }\end{array}$ & $\begin{array}{l}\mathrm{C} 1 \mathrm{INH} \text { reduced complement activation and improved } \\
\text { clinical outcome. }\end{array}$ & [45] \\
\hline & Meningitis & Mouse/Rat & $\begin{array}{l}\text { Effect on clinical illness, bacterial } \\
\text { clearance, and inflammatory response }\end{array}$ & C1 INH increased bacterial clearance. & [47] \\
\hline \multirow[t]{11}{*}{ Clinical } & Sepsis & Case series & Effect on functional levels on $\mathrm{C} 1 \mathrm{INH}$ & $\begin{array}{l}\mathrm{C} 1 \mathrm{INH} \text { may attenuate complement and contact } \\
\text { activation. }\end{array}$ & {$[49,50]$} \\
\hline & & $\begin{array}{l}\text { Double-blind } \\
\text { RCT }\end{array}$ & Efficacy and safety of $\mathrm{Cl} \mathrm{INH}$ & $\begin{array}{l}\text { C1 INH increased plasma C1 INH antigen and activity } \\
\text { levels during days } 1 \text { to } 4 \text { and lowered serum creatinine } \\
\text { concentrations on days } 3 \text { and } 4 \text {. Organ failure was less } \\
\text { pronounced. Mortality was unaffected. }\end{array}$ & [51] \\
\hline & & Case series & Effect on neutrophil activation & $\begin{array}{l}\text { Elastase-alpha(1)-antitrypsin complex and lactoferrin } \\
\text { levels were reduced. }\end{array}$ & [52] \\
\hline & & Open-label & Efficacy and safety of $\mathrm{Cl} \mathrm{INH}$ & $\begin{array}{l}\text { Complement activity was inhibited, and survival was } \\
\text { improved. }\end{array}$ & [53] \\
\hline & & Comparative & $\begin{array}{l}\text { To measure functional } \mathrm{C} 1 \mathrm{INH} \text { levels in } \\
\text { newborns with culture-proven sepsis }\end{array}$ & $\begin{array}{l}\text { There was no difference in functional } \mathrm{C} 1 \mathrm{INH} \text { levels } \\
\text { between treatment group and controls. }\end{array}$ & [54] \\
\hline & $\begin{array}{l}\text { Ischemia- } \\
\text { reperfusion } \\
\text { injury }\end{array}$ & Case series & $\mathrm{C} 1 \mathrm{INH}$ as rescue therapy & $\mathrm{C} 1 \mathrm{INH}$ restored myocardial function. & [55] \\
\hline & & Open-label & Effect of $\mathrm{C} 1 \mathrm{INH}$ following reperfusion & $\begin{array}{l}\text { 48-hour infusion of } \mathrm{C} 1 \mathrm{INH} \text { was safe and inhibited } \\
\text { complement activation. }\end{array}$ & [56] \\
\hline & & $\begin{array}{l}\text { Randomized, } \\
\text { double-bind }\end{array}$ & $\begin{array}{l}\text { Effects of } \mathrm{C} 1 \mathrm{INH} \text { in ST segment } \\
\text { elevation myocardial infarction }\end{array}$ & $\begin{array}{l}\text { Arterial pressure, cardiac index, and stroke volume } \\
\text { were improved in the C1 INH group. No adverse } \\
\text { effects were observed. }\end{array}$ & [58] \\
\hline & $\begin{array}{l}\text { Emergency } \\
\text { CABG }\end{array}$ & $\begin{array}{l}\text { Comparative, } \\
\text { open-label }\end{array}$ & $\begin{array}{l}\text { Effect of } \mathrm{C} 1 \text { INH on complement } \\
\text { activation, myocardial cell injury, and } \\
\text { clinical outcome }\end{array}$ & $\begin{array}{l}\text { Complement activity was reduced. There was no effect } \\
\text { on mortality. }\end{array}$ & [57] \\
\hline & Transplantation & $\begin{array}{l}\text { Comparative, } \\
\text { open-label }\end{array}$ & Efficacy & $\begin{array}{l}\text { In C1 INH patients, plasma levels of } \mathrm{C} 5 \mathrm{a} \text { and } \mathrm{C} 4 \mathrm{~d} \text { and } \\
\text { fluid levels were normalized. }\end{array}$ & [59] \\
\hline & & Case studies & - & $\begin{array}{l}\text { In case } 1 \text {, pleural effusions were reduced within } \\
12 \text { hours, leading to normal graft function within } \\
4 \text { days. In case } 2 \text {, pleural effusions were reduced from } \\
19 \mathrm{~L} \text { per day to } 300 \mathrm{~mL} \text { within } 3 \text { days of treatment. }\end{array}$ & [60] \\
\hline
\end{tabular}

C1 INH, C1-esterase inhibitor; CABG, coronary artery bypass grafting; LPS, lipopolysaccharide; RCT, randomized controlled trial; TNF- $a$, tumor necrosis factor-alpha.

kinase, troponin T, C3a, and C5a; and suppression of the endothelial expression of P-selectin and ICAM-1 (intercellular adhesion molecule-1) [27-30]. C1 INH also suppressed ischemia-reperfusion-induced apoptosis in rat myocardial cells with a possible effect on myocardial C3 expression [31,32].

Beneficial effects of $\mathrm{C} 1 \mathrm{INH}$ have also been described in a number of other animal ischemia-reperfusion models, including skeletal muscle, liver, cerebral artery, and mesenteric artery occlusion. These studies were reviewed in detail by Davis and colleagues [8]. More recently, $\mathrm{C} 1 \mathrm{INH}$ treatment reduced intestinal tissue injury, attenuated leukocyte infiltration, and improved survival in a murine model of intestinal ischemia-reperfusion injury [33]. The authors proposed that $\mathrm{C} 1 \mathrm{INH}$ may play a direct role in the suppression of leukocyte transmigration into reperfused tissue.

Complement and kinin pathways are also activated in acute pancreatitis [34]. C1 INH treatment ameliorated the degree of histological alterations in animal models of 
acute pancreatitis but did not improve survival [35]. Murine models demonstrate that C5a exerts an antiinflammatory effect in pancreatitis [36], but, to date, there is only limited evidence for the use of $\mathrm{C} 1 \mathrm{INH}$ in acute pancreatitis [35].

\section{Transplantation}

Antibody-mediated complement activation is implicated in transplant rejection [8,37]. C1 INH inhibited the action of porcine aortic cells incubated with human serum [38] and improved perfusion and survival of pig kidneys [39]. C1 INH has also been reported to provide some protection against injury in ex vivo mouse lung or pig lung whole human blood models [40-42]. C1 INH has also suppressed hyperacute and acute vascular rejection in porcine models $[43,44]$.

\section{Thermal injury}

Thermal injury is associated with profound immunologic alterations and activation of the complement system [45]. This association may play an important role in the development of capillary leak syndrome and inflammatory tissue destruction. In a porcine model, $\mathrm{C} 1 \mathrm{INH}$ treatment reduced complement activation by $50 \%$ and reduced edema formation [45]. These data suggest that $\mathrm{C} 1 \mathrm{INH}$ therapy may have a potential therapeutic role in the management of burn injury.

\section{Pneumococcal meningitis}

Complement-mediated opsonic activity may appear in the cerebrospinal fluid of patients who recover completely from bacterial meningitis and may influence the outcome of the disease [46]. In a rat model of meningitis, treatment with $\mathrm{C} 1 \mathrm{INH}$ was associated with reduced clinical severity, a less pronounced inflammatory infiltrate around the meninges, and lower brain levels of proinflammatory cytokines and chemokines. $\mathrm{C} 1 \mathrm{INH}$ treatment also increased bacterial clearance, possibly through an upregulation of CR3 [47]. These data suggest that C1 INH may be a useful agent in the treatment of pneumococcal meningitis. However, further clinical studies are needed in light of data from clinical studies of the monoclonal antibody eculizumab (that binds with high affinity to the complement protein C5) suggesting an increased risk of sepsis necessitating meningococcal vaccination 2 weeks prior to treatment [48].

\section{Clinical studies}

\section{Sepsis and endotoxic shock}

There are limited clinical data on the use of $\mathrm{C} 1 \mathrm{INH}$ in human sepsis. Early studies in small numbers of patients with septic shock reported that $\mathrm{C} 1 \mathrm{INH}$ treatment suppressed activation of the complement and contact systems $[49,50]$. These investigators then performed a double-blind study in 40 patients with severe sepsis or septic shock [51]. C1 INH was infused intravenously over the course of an hour, starting with 6,000 IU, followed by $3,000,2,000$, and 1,000 IU at 12-hour intervals. Patients treated with $\mathrm{C} 1 \mathrm{INH}$ had less severe multiple organ dysfunction and improved renal function, but there was no difference in mortality compared with the control group. The same group also reported that $\mathrm{C} 1 \mathrm{INH}$ reduced circulating elastase- $\alpha_{1}$-antitrypsin complex levels as well as complement activation and interleukin-8 release [52]. As neutrophils may contribute to the development of organ dysfunction during sepsis, the reduction in neutrophil count after $\mathrm{C} 1 \mathrm{INH}$ treatment may account in part for its favorable effect. A positive effect on mortality and an inhibitory effect of $\mathrm{C} 1 \mathrm{INH}$ (dose of 12,000 IU) on complement was also reported in an open-label Russian study of patients with sepsis [53].

In a recently published study, Tapisiz and colleagues [54] measured levels of C1 INH in 18 newborns who had had neonatal sepsis and who were blood culture-positive. These levels were repeated 48 hours later and compared against 23 healthy controls of the same gestational age. The authors reported no difference between the two groups and no difference in edema formation and concluded that, in neonates, other factors are responsible for vascular leak and edema [54].

\section{Ischemia-reperfusion injury}

Bauernschmitt and colleagues [55] reported on the use of $\mathrm{C} 1 \mathrm{INH}$ as salvage therapy in three patients following emergency surgical revascularization after failed percutaneous transluminal coronary angioplasty. Initially, a 2,000-unit bolus of $\mathrm{C} 1 \mathrm{INH}$ was administered, followed by 1,000 units at 12 and 24 hours after surgery. The authors reported rapid hemodynamic stabilization of all three patients. C1 INH therapy instituted after thrombolytic therapy was reported by de Zwaan and colleagues [56] to diminish complement activation and reduce troponin $\mathrm{T}$ and creatine kinase levels in patients with myocardial infarction by $36 \%$ and $57 \%$, respectively $(P=0.001)$. In a double-blind study of 57 patients undergoing emergency coronary artery bypass surgery, Thielmann and colleagues [57] also reported a reduction in cardiac troponin levels in the subgroup of patients treated with $\mathrm{C} 1 \mathrm{INH}$ before 6 hours.

The cardioprotective effects of $\mathrm{C} 1 \mathrm{INH}$ in ST segment elevation myocardial infarction in 80 patients undergoing emergent reperfusion with coronary artery bypass grafting were investigated in an Italian double-blind study [58]. The authors reported statistically significant differences between the $\mathrm{C} 1 \mathrm{INH}$-treated patients and controls for cardiopulmonary bypass support $(P=0.04)$, administration of high-dose inotropes $(P=0.001)$, time to intubation $(P=0.03)$, and intensive care and hospital 
lengths of stay $(P=0.04$ and 0.03 , respectively). Stroke volume $(P=0.03)$ and cardiac index $(P=0.02)$ were also significantly improved in the $\mathrm{C} 1 \mathrm{INH}$ group.

\section{Transplantation}

Nurnberger and colleagues [59] reported on the use of C1 INH in 15 patients with severe capillary leakage syndrome. Cumulative dosage was 180 units $/ \mathrm{kg}$ body weight (initial dose: 60 units $/ \mathrm{kg}$ followed by two doses at 30 units $/ \mathrm{kg}$ and four doses at 15 units/kg every 12 hours). One year after bone marrow transplantation, the survival rates were $57 \%$ in the $\mathrm{C} 1 \mathrm{INH}$ treatment group and $14 \%$ in the control group (7 patients not treated with $\mathrm{C} 1 \mathrm{INH}$ ) $(P=0.008)$. After infusion of $\mathrm{C} 1 \mathrm{INH}$, the plasma levels of $\mathrm{C} 5 \mathrm{a}$ and $\mathrm{C} 4 \mathrm{~d}$ normalized and the activity of $\mathrm{C} 1 \mathrm{INH}$ rose to $139 \% \pm 10 \%$ of normal human plasma (NHP) pool (mean \pm standard deviation).

Strüber and colleagues [60] reported the use of highdose $\mathrm{C} 1 \mathrm{INH}$ given over 2 days in two patients with graft failure either due to reperfusion injury immediately after transplantation or due to an acute rejection 2 months after double-lung transplantation. In both cases of graft failure, a capillary leak syndrome occurred with pleural effusions of from $7 \mathrm{~L}$ per day to more than $10 \mathrm{~L}$ per day. In one case, the disturbance of gas exchange during severe reperfusion injury could not be treated effectively with other treatment modalities such as nitric oxide ventilation or surfactant administration. With the use of C1 INH, pleural effusions decreased within 12 hours, leading to normal graft function within 4 days. In the second recipient, acute rejection forced the use of extracorporeal membrane oxygenation (ECMO) within 24 hours despite immunosuppressive therapy. After administration of $\mathrm{C} 1 \mathrm{INH}$, pleural effusions decreased from $19 \mathrm{~L}$ per day to $300 \mathrm{~mL}$ within 3 days of treatment. ECMO was discontinued after $\mathrm{C} 1 \mathrm{INH}$ treatment and the patient was extubated 2 weeks later [60].

\section{Thermal injury}

Kowal-Vern and colleagues [61] reported significant decreases in $\mathrm{C} 1 \mathrm{INH}$ levels $(P=0.0001)$ in 60 patients with thermal injuries and sepsis on the first day of admission, although this had increased to near-normal levels by day 5 .

\section{Conclusions}

$\mathrm{C} 1 \mathrm{INH}$ is a multifaceted anti-inflammatory protein that exerts its effects through a variety of mechanisms that may or may not depend on protease inhibition via covalent bonding [62] or other non-covalent interactions with proteins, cell surfaces, or lipids. C1 INH binds to a variety of extracellular matrix components, including type IV collagen, laminin, entactin, and fibrinogen. A non-covalent interaction with C3b inhibits formation of the alternative pathway C3 convertase, whereas an interaction with $\mathrm{E}$ and $\mathrm{P}$ selectins on endothelial cells is mediated by the Lewis $(\mathrm{x})$ tetrasaccharides expressed on C1 INH. These interactions result in suppression of leukocyte rolling and transmigration. A fourth interaction is the binding of $\mathrm{C} 1 \mathrm{INH}$ to Gram-negative bacterial endotoxin and this results in suppression of endotoxic shock by interfering with the interaction of endotoxin with its receptor complex on macrophages. Lastly, C1 INH binds directly to Gram-negative bacteria, leading to suppression of the development of sepsis, as demonstrated in the CLP model. It has been suggested that pharmacological inhibition of C5a or C5aR may be protective in sepsis [63].

As discussed above, C1 INHs are currently licensed for routine prophylaxis and treatment of angioedema attacks in adolescents and adults. C1 INHs have also been used for the treatment of RAAS (renin-angiotensin-aldosterone system) blocker-induced angioedema and acquired angioedema. Other therapeutic options for bradykinin-mediated angioedema include inhaled epinephrine, corticosteroids, bradykinin receptor antagonists (icatibant), and the plasma kallikrein inhibitor ecallantide $[9,64,65]$. $\mathrm{C} 1$ INHs have been shown to be beneficial not only in sepsis and Gram-negative endotoxic shock but also in vascular leak syndrome, transplant rejection ischemia-reperfusion injury, intestinal ischemia and reperfusion, pancreatitis, and burns. However, serious thrombogenesis has been reported following high-dose use of human $\mathrm{C} 1 \mathrm{INH}$ in neonatal patients undergoing cardiac surgery using an extracorporeal circulation [64]. C1 INHs may also have a role in the treatment of cerebral malaria [66]. Clinical studies and well-designed dose-titrating studies are needed to clarify the levels of C1 INH needed to produce a therapeutic effect and to establish whether treatment with C1 INH has a place in the management of these conditions. Other infections in which the inflammatory response contributes to mortality, such as pneumonia and peritonitis, may also be worthy of examination.

\section{Abbreviations \\ C1 INH, C1-esterase inhibitor; C5aR, C5a receptor; CLP, cecal ligation and puncture; ECMO, extracorporeal membrane oxygenation; PMN polymorphonuclear neutrophil.}

\section{Competing interests}

This work was undertaken in part at University College London Hospitals/ University College London (UCLH/UCL), which receives a proportion of its funding from the funding scheme of the UK Department of Health's National Institute for Health Research (NIHR) Biomedical Research Centre. This article was funded by an unrestricted educational grant from ViroPharma Incorporated (Exton, PA, USA). AJ has worked as an external consultant for ViroPharma Incorporated. MS and AJ have no non-financial competing interests to declare.

\section{Author details}

'Bloomsbury Institute of Intensive Care Medicine, University College London, Cruciform Building, Gower Street, London, WC1E 6BT, UK. ' MSC Ltd, Marr House, Scagglethorpe, Malton, N Yorks, YO17 8ED, UK. 


\section{Acknowledgments}

Editorial support was provided by Innovative Strategic Communications LLC (Stamford, CT, USA) and was funded by ViroPharma Incorporated.

\section{Published: 26 January 2011}

\section{References}

1. Rambach G, Wurzner R, Speth C: Complement: an efficient sword of innate immunity. Contrib Microbio/ 2008, 15:78-100.

2. McPhaden AR, Whaley $\mathrm{K}$ : The complement system in sepsis and trauma. $\mathrm{Br}$ Med Bull 1985, 41:281-286.

3. Stoner HB: Interpretation of the metabolic effects of trauma and sepsis. J Clin Pathol 1987, 40:1108-1117.

4. Ward PA: Sepsis, apoptosis and complement. Biochem Pharmacol 2008, 76:1383-1388.

5. Ward PA, Gao H: Sepsis, complement, and the dysregulated inflammatory response. J Cell Mol Med 2009, 13:4154-4160.

6. Ward PA: Role of the complement in experimental sepsis. J Leukoc Biol 2008, 83:467-470

7. Rittirsch D, Flierl MA, Ward PA: Harmful molecular mechanisms in sepsis. Nat Rev Immunol 2008, 8:776-787.

8. Davis AE 3rd, Mejia P, Lu F: Biological activities of C1 inhibitor. Mol Immunol 2008, 45:4057-4063.

9. Bas M, Adams V, Suvorava T, Niehues T, Hoffmann TK, Kojda G: Nonallergic angioedema: role of bradykinin. Allergy 2007, 62:842-856.

10. Cai S, Dole VS, Bergmeier W, Scafidi J, Feng H, Wagner DD, Davis AE 3rd: A direct role for $\mathrm{C} 1$ inhibitor in regulation of leukocyte adhesion. J Immunol 2005, 174:6462-6466.

11. Beinrohr L, Harmat V, Dobo J, Lorincz Z, Gal P, Zavodszky P: C1 inhibitor serpin domain structure reveals the likely mechanism of heparin potentiation and conformational disease. J Biol Chem 2007, 282:21100-21109.

12. Landerman NS, Webster ME, Becker EL, Ratcliffe HE: Hereditary angioneurotic edema. II. Deficiency of inhibitor for serum globulin permeability factor and/or plasma kallikrein. J Allergy 1962, 33:330-341.

13. Albrecht EA, Ward PA: Complement-induced impairment of the innate immune system during sepsis. Curr Infect Dis Rep 2005, 7:349-354.

14. Monefeldt $\mathrm{K}$, Helgeland $\mathrm{K}$, Tollefsen $\mathrm{T}$ : In vitro activation of the classical pathway of complement by a streptococcal lipoteichoic acid. Oral Microbiol Immunol 1994, 9:70-76.

15. Flierl MA, Rittirsch D, Nadeau BA, Day DE, Zetoune FS, Sarma JV, Huber-Lang MS, Ward PA: Functions of the complement components $\mathrm{C} 3$ and $\mathrm{C} 5$ during sepsis. FASEB J 2008, 22:3483-3490.

16. Rittirsch D, Flierl MA, Nadeau BA, Day DE, Huber-Lang M, Mackay CR, Zetoune FS, Gerard NP, Cianflone K, Köhl J, Gerard C, Sarma JV, Ward PA: Functional roles for C5a receptors in sepsis. Nat Med 2008, 14:551-557.

17. Niederbichler AD, Hoesel LM, Westfall MV, Gao H, Ipaktchi KR, Sun L, Zetoune FS, Su GL, Arbabi S, Sarma JV, Wang SC, Hemmila MR, Ward PA: An essential role for complement C5a in the pathogenesis of septic cardiac dysfunction. J Exp Med 2006, 203:53-61.

18. Croner RS, Lehmann TG, Fallsehr C, Herfarth C, Klar E, Kirschfink M: C1inhibitor reduces hepatic leukocyte-endothelial interaction and the expression of VCAM-1 in LPS-induced sepsis in the rat. Microvasc Res 2004, 67:182-191.

19. Schmidt W, Stenzel K, Walther A, Gebhard MM, Martin E, Schmidt H: Influence of $\mathrm{C} 1$-esterase inhibitor on tissue oxygenation of jejunal mucosa during endotoxemia. Int J Surg Investig 1999, 1:277-283.

20. Lehmann C, Birnbaum J, Lührs C, Rückbeil O, Spies C, Ziemer S, Gründling M, Pavlovic D, Usichenko T, Wendt M, Kox WJ: Effects of C1 esterase inhibitor administration on intestinal functional capillary density, leukocyte adherence and mesenteric plasma extravasation during experimental endotoxemia. Intensive Care Med 2004, 30:309-314.

21. Fischer MB, Prodeus AP, Nicholson-Weller A, Ma M, Murrow J, Reid RR, Warren HB, Lage AL, Moore FD Jr., Rosen FS, Carroll MC: Increased susceptibility to endotoxin shock in complement C3- and C4-deficient mice is corrected by C1 inhibitor replacement. J Immunol 1997, 159:976-982.

22. Giebler R, Schmidt U, Koch S, Peters J, Scherer R: Combined antithrombin III and $\mathrm{C} 1$-esterase inhibitor treatment decreases intravascular fibrin deposition and attenuates cardiorespiratory impairment in rabbits exposed to Escherichia coli endotoxin. Crit Care Med 1999, 27:597-604.

23. Guerrero R, Velasco F, Rodriguez M, Lopez A, Rojas R, Alvarez MA, Villalba R,
Rubio V, Torres A, del Castillo D: Endotoxin-induced pulmonary dysfunction is prevented by C1-esterase inhibitor. J Clin Invest 1993, 91:2754-2760.

24. Jansen PM, Eisele B, de Jong IW, Chang A, Delvos U, Taylor FB Jr, Hack CE: Effect of $\mathrm{C} 1$ inhibitor on inflammatory and physiologic response patterns in primates suffering from lethal septic shock. J Immunol 1998, 160:475-484.

25. Liu D, Cai S, Gu X, Scafidi J, Wu X, Davis AE 3rd: C1 inhibitor prevents endotoxin shock via a direct interaction with lipopolysaccharide. J Immunol 2003, 171:2594-2601.

26. Liu D, Lu F, Qin G, Fernandes SM, Li J, Davis AE 3rd: C1 inhibitor-mediated protection from sepsis. J Immuno/ 2007, 179:3966-3972.

27. Buerke M, Murohara T, Lefer AM: Cardioprotective effects of a C1 esterase inhibitor in myocardial ischemia and reperfusion. Circulation 1995, 91:393-402.

28. Buerke M, Prufer D, Dahm M, Oelert H, Meyer J, Darius H: Blocking of classical complement pathway inhibits endothelial adhesion molecule expression and preserves ischemic myocardium from reperfusion injury. J Pharmacol Exp Ther 1998, 286:429-438.

29. Horstick G, Heimann A, Götze O, Hafner G, Berg O, Böhmer P, Becker P, Darius H, Rupprecht HJ, Loos M, Bhakdi S, Meyer J, Kempski O: Intracoronary application of $\mathrm{C} 1$ esterase inhibitor improves cardiac function and reduces myocardial necrosis in an experimental model of ischemia and reperfusion. Circulation 1997, 95:701-708.

30. Horstick G, Berg O, Heimann A, Götze O, Loos M, Hafner G, Bierbach B, Petersen S, Bhakdi S, Darius H, Horstick M, Meyer J, Kempski O: Application of C1-esterase inhibitor during reperfusion of ischemic myocardium: doserelated beneficial versus detrimental effects. Circulation 2001, 104:3125-3131.

31. Fu J, Lin G, Wu Z, Ceng B, Wu Y, Liang G, Qin G, Li J, Chiu I, Liu D: Antiapoptotic role for $\mathrm{C} 1$ inhibitor in ischemia/reperfusion-induced myocardial cell injury. Biochem Biophys Res Commun 2006, 349:504-512.

32. Fu J, Lin G, Zeng B, Wu Z, Wu Y, Chu H, Qin G, Liang G, Li J, Gan X, Yu X, Li C, Liu D: Anti-ischemia/reperfusion of C1 inhibitor in myocardial cell injury via regulation of local myocardial C3 activity. Biochem Biophys Res Commun 2006, 350:162-168.

33. Lu F, Chauhan AK, Fernandes SM, Walsh MT, Wagner DD, Davis AE 3rd: The effect of $\mathrm{C} 1$ inhibitor on intestinal ischemia and reperfusion injury. $\mathrm{Am}$ Physiol Gastrointest Liver Physiol 2008, 295:G1042-1049.

34. Frossard JL, Steer ML, Pastor CM: Acute pancreatitis. Lancet 2008, 371:143-152.

35. Niederau C, Brinsa R, Niederau M, Luthen R, Strohmeyer G, Ferrell LD: Effects of $\mathrm{C} 1$-esterase inhibitor in three models of acute pancreatitis. Int J Pancreatol 1995, 17:189-196.

36. Bhatia M, Saluja AK, Singh VP, Frossard JL, Lee HS, Bhagat L, Gerard C, Steer $\mathrm{ML}$ : Complement factor $\mathrm{C5}$ a exerts an anti-inflammatory effect in acute pancreatitis and associated lung injury. Am J Physiol Gastrointest Liver Physiol 2001, 280:G974-978.

37. Tomasdottir H, Henriksson BA, Bengtson JP, Bengtsson A, Stenqvist O, Persson $\mathrm{H}$ : Complement activation during liver transplantation. Transplantation 1993, 55:799-802.

38. Dalmasso AP, Platt JL: Prevention of complement-mediated activation of xenogeneic endothelial cells in an in vitro model of xenograft hyperacute rejection by C1 inhibitor. Transplantation 1993, 56:1171-1176.

39. Fiane AE, Videm V, Johansen HT, Mellbye OJ, Nielsen EW, Mollnes TE: C1-inhibitor attenuates hyperacute rejection and inhibits complement, leukocyte and platelet activation in an ex vivo pig-to-human perfusion model. Immunopharmacology 1999, 42:231-243.

40. Pöling J, Oezkur M, Kogge K, Mengel M, Niemann H, Winkler M, Haverich A, Wiebe K: Hyperacute rejection in ex vivo-perfused porcine lungs transgenic for human complement regulatory proteins. Transp/ Int 2006 , 19:225-232.

41. Schelzig H, Simon F, Krischer C, Vogel A, Abendroth D: Ex-vivo hemoperfusion (eHPS) of pig-lungs with whole human blood: effects of complement inhibition with a soluble C1-esterase-inhibitor. Ann Transplant 2001, 6:34-39.

42. Schröder C, Pfeiffer S, Wu G, Zorn GL 3rd, Ding L, Allen C, Harrison RA, White DJ, Azimzadeh AM, Pierson RN 3rd: Effect of complement fragment 1 esterase inhibition on survival of human decay-accelerating factor pig lungs perfused with human blood. J Heart Lung Transplant 2003, 22:1365-1375

43. Hecker JM, Lorenz R, Appiah R, Vangerow B, Loss M, Kunz R, Schmidtko J, 
Mengel M, Klempnauer J, Piepenbrock S, Dickneite G, Neidhardt H, Rückoldt H, Winkler M: C1-inhibitor for prophylaxis of xenograft rejection after pig to cynomolgus monkey kidney transplantation. Transplantation 2002, 73:688-694.

44. Hecker JM, Loss M, Klempnauer J, Winkler M: C1-inhibitor for therapy and prophylaxis of acute vascular rejection of porcine kidneys in cynomolgus monkeys. Transplant Proc 2002, 34:2382.

45. Radke A, Mottaghy K, Goldmann C, Khorram-Sefat R, Kovacs B, Janssen A, Klosterhalfen B, Hafemann B, Pallua N, Kirschfink M: C1 inhibitor prevents capillary leakage after thermal trauma. Crit Care Med 2000, 28:3224-3232.

46. Zwahlen A, Nydegger UE, Vaudaux P, Lambert PH, Waldvogel FA: Complement-mediated opsonic activity in normal and infected human cerebrospinal fluid: early response during bacterial meningitis. J Infect Dis 1982, 145:635-646.

47. Zwijnenburg PJ, van der Poll T, Florquin S, Polfliet MM, van den Berg TK, Dijkstra CD, Roord JJ, Hack CE, van Furth AM: C1 inhibitor treatment improves host defense in pneumococcal meningitis in rats and mice. $J$ Infect Dis 2007, 196:115-123.

48. Charneski L, Patel PN: Eculizumab in paroxysmal nocturnal haemoglobinuria. Drugs 2008, 68:1341-1346.

49. Hack CE, Voerman HJ, Eisele B, Keinecke HO, Nuijens JH, Eerenberg AJ, Ogilvie A, Strack van Schijndel RJ, Delvos U, Thiij LG: C1-esterase inhibitor substitution in sepsis. Lancet 1992, 339:378.

50. Hack CE, Ogilvie AC, Eisele B, Jansen PM, Wagstaff J, Thiis LG: Initial studies on the administration of C1-esterase inhibitor to patients with septic shock or with a vascular leak syndrome induced by interleukin-2 therapy. Prog Clin Biol Res 1994, 388:335-357.

51. Caliezi C, Zeerleder S, Redondo M, Regli B, Rothen HU, Zürcher-Zenklusen R, Rieben R, Devay J, Hack CE, Lämmle B, Wuillemin WA: C1-inhibitor in patients with severe sepsis and septic shock: beneficial effect on renal dysfunction. Crit Care Med 2002, 30:1722-1728.

52. Zeerleder S, Caliezi C, van Mierlo G, Eerenberg-Belmer A, Sulzer I, Hack CE, Wuillemin WA: Administration of $\mathrm{C} 1$ inhibitor reduces neutrophil activation in patients with sepsis. Clin Diagn Lab Immunol 2003, 10:529-535.

53. Lazareva NB, Igonin AA: [Safety and efficacy of purified human C1-esterase inhibitor in the treatment of patients with sepsis]. Antibiot Khimioter 2009, 54:42-46.

54. Tapisiz A, Ergenekon E, Oktem M, Koc E, Okumus N, Zenciroğlu A, Atalay Y $\mathrm{C} 1$ inhibitor level on neonatal sepsis and its relations with clinical findings. I Paediatr Child Health 2010, 46:121-124.

55. Bauernschmitt R, Bohrer $H$, Hagl S: Rescue therapy with C1-esterase inhibitor concentrate after emergency coronary surgery for failed PTCA. Intensive Care Med 1998, 24:635-638.
56. de Zwaan C, Kleine AH, Diris JH, Glatz JF, Wellens HJ, Strengers PF, Tissing M, Hack CE, van Dieijen-Visser MP, Hermens WT: Continuous 48-h C1-inhibitor treatment, following reperfusion therapy, in patients with acute myocardial infarction. Eur Heart J 2002, 23:1670-1677.

57. Thielmann M, Marggraf G, Neuhäuser M, Forkel J, Herold U, Kamler M, Massoudy P, Jakob H: Administration of C1-esterase inhibitor during emergency coronary artery bypass surgery in acute ST-elevation myocardial infarction. Eur J Cardiothorac Surg 2006, 30:285-293.

58. Fattouch K, Bianco G, Speziale G, Sampognaro R, Lavalle C, Guccione F, Dioguardi $\mathrm{P}$, Ruvolo G: Beneficial effects of $\mathrm{C} 1$ esterase inhibitor in ST-elevation myocardial infarction in patients who underwent surgical reperfusion: a randomised double-blind study. Eur J Cardiothorac Surg 2007, 32:326-332.

59. Nurnberger W, Heying R, Burdach S, Gobel U: C1 esterase inhibitor concentrate for capillary leakage syndrome following bone marrow transplantation. Ann Hematol 1997, 75:95-101.

60. Strüber M, Hagl C, Hirt SW, Cremer J, Harringer W, Haverich A: C1-esterase inhibitor in graft failure after lung transplantation. Intensive Care Med 1999, 25:1315-1318

61. Kowal-Vern A, Walenga JM, Sharp-Pucci M, Hoppensteadt D, Gamelli RL Postburn edema and related changes in interleukin-2, leukocytes, platelet activation, endothelin-1, and C1 esterase inhibitor. J Burn Care Rehabil 1997. 18:99-103.

62. Davis AE 3rd, Cai S, Liu D: C1 inhibitor: biologic activities that are independent of protease inhibition. Immunobiology 2007, 212:313-323.

63. Guo RF, Ward PA: C5a, a therapeutic target in sepsis. Recent Pat Antiinfect Drug Discov 2006, 1:57-65.

64. Drug Commission of the German Medical Profession: Serious Thrombogenesis Following Berinert HS. Dtsch Arzteb/ 2000, 97:A-1016/B-864/C-812.

65. Temino VM, Peebles RS Jr.: The spectrum and treatment of angioedema. Am J Med 2008, 121:282-286.

66. Lou J, Lucas R, Grau GE: Pathogenesis of cerebral malaria: recent experimental data and possible applications for humans. Clin Microbiol Rev 2001, 14:810-820.

67. Levinson WE: Review of Medical Microbiology and Immunology. 9th edition. New York: McGraw-Hill Medical; 2006.

doi:10.1186/cc9304

Cite this article as: Singer M, Jones AM: Bench-to-bedside review: The role of C1-esterase inhibitor in sepsis and other critical illnesses. Critical Care 2011, 15:203 